\title{
\#EdTechHub
}

Realising the potential of technology in education

\section{EdTech in Zimbabwe: A Rapid Scan}

Monica Dzinotyiweyi and Abeba Taddese

EdTech Hub, https://edtechhub.org

Country Scan

2020-06-30

DOI: $10.5281 /$ zenodo.3903838

For enquiries please email helpdesk@edtechhub.org

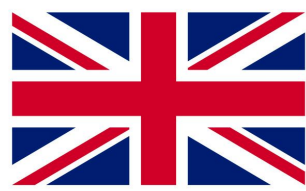




\section{About this document}

Recommende Dzinotyiweyi, M, and Taddese, A. (2020). EdTech in Zimbabwe: A Rapid d citation. Scan. (EdTech Hub Country Scan). DOI: 10.5281/zenodo.3903838.

Available from https://docs.edtechhub.org/lib/G4UUX5P3. Available under Creative Commons Attribution 4.0 International, https://creativecommons.org/licenses/by/4.0/.

Licence. Creative Commons Attribution 4.0 International

https://creativecommons.org/licenses/by/4.0/.

You - dear readers - are free to share (copy and redistribute the material in any medium or format) and adapt (remix, transform, and build upon the material) for any purpose, even commercially. You must give appropriate credit, provide a link to the license, and indicate if changes were made. You may do so in any reasonable manner, but not in any way that suggests the licensor endorses you or your use.

\section{Creative N/A \\ Commons \\ Acknow- \\ ledgement}

Identifiers. $\quad$ 2405685:G4UUX5P3; 10.5281/zenodo.3903838.

Internal use. g/d/1gXt32bCN3RcRPE2OrZMJQYPPyHtghah2s53epUGSYoE

Reviewed by Tapfuma Ronald Jongwe, Education Specialist, World Bank

Notes. $\quad$ The EdTech Hub is supported by UK aid from the UK government; however the views expressed are the views of the authors and do not necessarily reflect views of our donors. 


\section{About this scan}

EdTech Hub country scans explore factors that enable and hinder the use of technology in education. These factors include the policy or vision for EdTech, institutional capacity, private-sector partnerships, and the digital infrastructure. The scans are intended to be comprehensive but are by no means exhaustive. However, we hope they will serve as a useful starting point for more in-depth discussions about opportunities and barriers in EdTech in specific countries, in this case, Zimbabwe.

This report was originally written in June 2020. It is based primarily on desk research, with quality assurance provided by a country expert. Given how rapidly the educational technology landscape is evolving, the Hub plans to provide periodic updates. Table 1 provides a summary of the situation regarding EdTech in Zimbabwe.

\section{Table 1. EdTech in Zimbabwe}

\begin{tabular}{|c|c|}
\hline Policies & $\begin{array}{l}\text { - Zimbabwe has a National ICT Policy that acknowledges a role for } \\
\text { ICTs in the education sector (Ministry of ICT, Postal and Courier } \\
\text { Services, 2016). While the policy is dated 2016, it was launched in } \\
2018 \text { (Musarurwa, 2018). } \\
\text { - An ICT Policy for Primary and Secondary Education (2019-2023) } \\
\text { was launched in October } 2019\end{array}$ \\
\hline cture & $\begin{array}{l}\text { - } 55 \% \text { of primary schools have access to electricity, and } 26 \% \text { have } \\
\text { internet connectivity } \\
\text { - } 71 \% \text { of secondary schools have access to electricity, and } 43 \% \\
\text { have internet connectivity } \\
\text { - The average number of computers per primary school is 6; on } \\
\text { average there are } 123 \text { primary school learners per computer } \\
\text { - The average number of computers per secondary school is 18; } \\
\text { on average there are } 36 \text { primary school learners per computer } \\
\text { - There are disparities in access to electricity and ICT across urban } \\
\text { and rural regions. Urban schools have higher access to electricity } \\
\text { and connectivity than rural schools }\end{array}$ \\
\hline $\begin{array}{l}\text { Partners and } \\
\text { initiatives }\end{array}$ & $\begin{array}{l}\text { - Over the years, the Ministry of Primary and Secondary } \\
\text { Education (MoPSE) has supported several initiatives aimed at } \\
\text { strengthening the use of ICTs in education, such as the Schools } \\
\text { Computerisation Programme launched in } 2000 \text {, the Presidential } \\
\text { e-Learning Programme of 2011, and the Electronic Ministry } \\
\text { Application Platform introduced in } 2016 \text {. } \\
\text { - UNESCO has been a core supporter of EdTech initiatives in }\end{array}$ \\
\hline
\end{tabular}




\begin{tabular}{|c|c|}
\hline & Zimbabwe. \\
\hline Covid-19 & $\begin{array}{l}\text { - In response to the Covid-19 pandemic, all schools closed on } \\
\text { March 24, 2020, affecting approximately } 5.7 \text { million learners } \\
\text { (aged 3-18) (2019 Primary and Secondary Education Statistics } \\
\text { Report) } \\
\text { - On May 4, 2020, in collaboration with the Education Cluster } \\
\text { partners, MoPSE published its Covid-19 Preparedness and } \\
\text { Response Strategy (Zimbabwe Education Cluster, 2020) } \\
\text { - On June 3, 2020, MoPSE and the Zimbabwe Broadcasting } \\
\text { Corporation announced the launch of radio lessons in response } \\
\text { to the pandemic }\end{array}$ \\
\hline
\end{tabular}

\section{Country overview}

According to the 2012 census, Zimbabwe's population stood at 13.06 million.

Sixty-seven per cent live in rural areas where the majority of livelihoods are dependent on rain-fed agriculture. Fifty-one percent of the population is of school-going age. With an annual population growth rate of $2.2 \%$, it is projected that by 2022 the school-age population will have increased by $12.7 \%$.

The main pillars of Zimbabwe's economy are agriculture, mining, manufacturing and tourism. The period 1998 to 2008 was particularly challenging, as the country experienced a decade-long economic decline, with high inflation and low investment (Ministry of Primary and Secondary Education, 2016). From 2009 to 2014, the economy registered modest growth. GDP growth has since slowed as a result of several factors that include depressed mineral prices on the world market, declining capacity in the industrial sector, and limited foreign direct investment (FDI). The contraction of agricultural production following an El Nino-induced drought had a negative effect on the economy, especially in rural areas. The drought additionally impacted the electricity and water sectors, leading to widespread rationing and tariff adjustments to help manage costs. The 2019 Cyclone Idai - one of the worst tropical cyclones on record in Southern Africa - worsened the situation in three key provinces that typically account for $30 \%$ of agricultural output.

The contracting economy has also affected the education sector. Rising inflation has reduced the purchasing power and ability of parents to pay school fees and levies, resulting in poorly equipped learning environments for which parents continue to shoulder the costs of school facilities and supplies (Ngwenya, 2018). Today, the country remains in debt distress, with large external arrears to official creditors (World Bank, 2019).

\section{Education system overview}

In this section, we first provide an overview of the education policy and system structure in Zimbabwe, followed by a closer look at progress made and challenges faced by the 
education sector with regard to financing, infrastructure, quality and teachers' digital skills. It concludes with an outline of the 2016 Education Sector Plan.

\subsection{Education policy and system structure}

Zimbabwe's school system is regulated through the Education Act of 1987 that provides for the establishment, maintenance and regulation of schools, the registration and control of educational institutions, and the transfer of teachers to the civil service (Government of Zimbabwe, 1987). An Education Amendment Act was introduced in March 2020, to align the 1987 Education Act with the country's new 2013 constitution (Government of Zimbabwe, 2019). Notably, the Amendment prohibits cruel and inhumane disciplinary measures in schools, establishing that, "under no circumstances is a teacher allowed to beat a child." Additionally, the Amendment introduces basic, state-funded education for which students will not be required to pay fees, requires all schools to ensure appropriate infrastructure for learners with disabilities, and guarantees that students will not be excluded from school because of pregnancy.

Zimbabwe is divided into 10 provinces and has 72 education districts. In 2018 there were 6,288 primary schools and 2,871 secondary schools (Ministry of Primary and Secondary Education, 2016). According to the Annual Education Statistics Report (2018), there are 2,725,970 primary school learners and 1,093,550 secondary school learners in the country; approximately three-quarters of learners live in rural areas (Ministry of Primary and Secondary Education, 2018). Primary and secondary education is delivered by government and non-governmental providers, under the overall supervision of the MoPSE. Zimbabwe's education system is organised in four tiers (see Table 2).

Table 2. Education system tiers

\begin{tabular}{|l|l|l|}
\hline Education Level & Grades & Age (years) \\
\hline Infant Education & $\begin{array}{l}\text { Early Childhood Development } \\
\text { Grades 1 and 2 }\end{array}$ & $\begin{array}{l}4-5 \\
6-7\end{array}$ \\
\hline Junior Education & Grades 3-7 & $8-12$ \\
\hline Lower Secondary & Forms 1-4 ('O' Level examinations) & $13-16$ \\
\hline Upper Secondary & Forms 5-6 ('A' Level examinations) & $17-18$ \\
\hline
\end{tabular}

The Zimbabwe School Examinations Council (ZIMSEC), a parastatal of the MoPSE, administers and manages all national examinations which include the Zimbabwe Early Learning Assessment (ZELA), Grade 7 examinations, 'O' Level and 'A' Level. A growing number of private schools offer these examinations through the Cambridge International curriculum (Kadirire, 2020).

The Education Coordination Group (ECG) is a national forum that coordinates sector developmental issues. It consists of MoPSE senior management, other sector ministries, civil society organisations, the World Bank, DFID, and UN partners - with UNICEF serving as its secretariat. There is also a Steering Committee (SC) that meets once every 
quarter to make policy decisions and an Implementation Committee that monitors progress on the implementation of programmes as well as the decisions made by the ECG and SC.

\subsection{Education sector progress and challenges}

Net Enrolment Rates (NER) for Early Childhood Development, Grades 1 and 2, and Junior Education (Grade 3-7) are 15.20\%, 31.29\% and 80.67\%, respectively. The NER for primary school is $91.91 \%$, but only $56.4 \%$ for secondary school (Forms $1-4)$. The transition rate from primary to lower secondary is $73.4 \%$, and the transition rate from lower to upper secondary is $11.38 \%$ (Ministry of Primary and Secondary Education, 2018). The low percentage reflects in part, a system in which only those who pass the ' $O$ ' Level exam proceed to the upper secondary level, which in turn, results in low levels of university enrollment. Students who do not pass the exam enrol in other tertiary institutions such as polytechnics, technical colleges, teacher's colleges, etc. Using the proportion of learners who have at least completed short-cycle tertiary education and the low ' $\mathrm{O}$ ' level pass rates, one can infer that the majority of post-secondary learners are either in the labour market or are unemployed. The probability of not continuing in schools is twice as high for students from poor households (Ministry of Primary and Secondary Education, 2016).

\subsubsection{Financing of education}

While MoPSE's budget has increased substantially - accounting for $22 \%$ of total government expenditure - more than $97 \%$ of the budget goes to pay teachers' salaries. However, salaries for the majority of teachers are at the Total Poverty Consumption Line for a family of five (Ibid.) and contribute to low staff morale. In 2013, primary- and secondary-school-level parent fees and levies accounted for $96 \%$ of non-teacher salary income (a total of $\$ 779$ million) (lbid.). The fees and levies contribute to inequities in infrastructure and access to teaching and learning materials in communities that cannot raise adequate resources.

In addition to a lack of fiscal space in the budget for non-salary expenditures, other challenges in the sector are discussed below.

\subsubsection{Infrastructure}

An insufficient number of classrooms and poor state of repair contributes to large class sizes. Additionally, most classrooms do not have ICT laboratories or centres. Where they exist, they are often poorly equipped. The EMIS (2014) data show a deficit of 33,636 classrooms across the country and indicate $50 \%$ of all classrooms are in need of repairs (Ibid.). Student numbers are expected to increase in the years ahead, due to the high population growth rate, and will put further pressure on already weakened school infrastructure.

\subsubsection{Quality of education}

The pass rates of students taking national examinations at Grade 7 and in Form 4 shows an increase since 2009 , however, there has been a decrease in success at 'A' level. While 
the ' $O$ ' level pass rate has been steadily increasing, in 2019 it remained at a low rate of $34 \%$, suggesting a need for measures to improve quality in secondary education (Ministry of Primary and Secondary Education, 2019: 206)

\subsubsection{Low EdTech / digital skills of teachers}

Although the percentage of trained teachers at the primary and secondary levels is high, only about $15 \%$ of primary teachers have minimum basic computer skills while less than $2 \%$ of secondary teachers are specialist teachers in computer science (Ministry of Primary and Secondary Education, 2018).

\subsection{Education Sector Strategic Plan}

The priorities articulated in the Education Sector Strategic Plan (ESSP) (2016) are:

- The introduction, monitoring and adjustment of the new curriculum from infant to the upper secondary levels.

- An infrastructure programme that addresses:

- an increased number of students as a result of the population increase;

- the expected increase in completion at secondary level as a result of improved learning in junior schools; and the expected increase in children currently not in school but entering as a result of non-formal education (NFE) programmes providing pathways back into school;

$\circ$ the new curriculum which requires access to specialist rooms for ICT and STEM;

○ inclusive learning environments;

- age-appropriate infrastructure and furniture;

- large-scale maintenance and renovation.

- A teacher-quality improvement programme that will take place as a part of the introduction of the new curriculum. There is also a planned expansion and operationalisation of the Teacher Management Information System and establishment of a Teacher Council.

- Institutional structures and skills development for leaders, managers and administrators at National, Provincial, District and school levels will be implemented.

- The research and development capacity of MoPSE will be developed in order to:

- strengthen the capacity of the Planning and Research Department, enabling it to provide accurate and timely data that have been analysed, to inform the ESSP policy goals, and to inform specific areas of policymaking;

- establish a Centre for Education Research, Innovation and Development (CERID) that conducts research to inform policy and practice-level priorities. 


\section{EdTech policy and strategy}

In this section, we describe national and education ICT policies, considering the latter in greater detail, including long-term strategy.

\subsection{National policy}

Five out of eleven of the objectives in the national ICT Policy (2016) relate to ICT in education and human resources (Ministry of ICT, Postal and Courier Services, 2016). The policy articulates the aim of providing connectivity in all schools in order to bridge the urban-rural digital divide, and to enhance teaching and learning through the use of technology. The objectives and strategies include:

- Working with relevant institutions and government departments to develop programmes that increase ICT human resource capacity and skills;

- Facilitating the deployment and exploitation of ICTs in the education system from primary school upwards;

- Working with the relevant ministries to include ICT training and education in schools, colleges and universities;

- Providing equitable access to ICT-enabled education and training in all parts of the country, including disadvantaged communities;

- Promoting e-learning and use of e-learning materials throughout Zimbabwe;

- Making use of the Universal Service Fund (USF) to boost connectivity for remotely located schools, in order to facilitate the National e-Learning Programme;

- Encouraging, promoting and applying research and development in ICTs in society.

\subsection{ICT in education policy}

The ICT Policy for Primary and Secondary Education (2019-2023) aligns with the Constitution, Zimbabwe Agenda for Sustainable Socio-Economic Transformation (ZIMASSET), Education Act, National Policy for ICT, Education Sector Strategic Plan, and other key documents that relate to access to education and training.

The vision for the ICT Policy for Primary and Secondary education is:

"ICTs being used effectively and efficiently throughout the education sector enabling all learners to achieve their full potential and become productive responsible citizens" (Ministry of Primary and Secondary Education, 2019).

Additionally, the policy states:

"The Government of Zimbabwe through the Ministry of Primary and Secondary Education commits to the use of ICT as an enabler for education in order to create, promote and sustain the development of a knowledgeable, innovative and creative society which ultimately supports the national agenda of attaining a knowledge-based society" (Ministry of Primary and Secondary Education, 2019).

The policy describes action areas in four key domains as listed below: 
1. Technical Infrastructure:

a. All schools connected to the WAN (wide area network) and high-speed broadband internet.

b. All learners provided with daily access to ICTs and adaptive technologies to support their learning.

2. E-Resources:

a. Universal access to high-quality digital learning resources provided in all schools to meet the needs of all learners.

b. ICTs integrated and applied across the entire curriculum at all levels for all learners.

3. Capacity Building:

a. All teachers and school administrators proficient in the use of ICT and using them daily in their work.

b. ICT tools being used by all learners to support e-learning and all teaching and learning activities.

c. All MoPSE personnel proficient in the use of ICTs and using them daily in their work.

4. Sustainability:

a. Cost-effective, ICT-based and digitised operational activities for MoPSE.

b. Public-private partnerships to support and ensure effective ICT use in schools established and institutionalised.

\section{ICT infrastructure}

At the national level, household ownership of mobile phones is high (89.4\%) but low for computers (15.2\%) (Table 3).

Table 3. Household ownership of technology (UNICEF, 2020)

\begin{tabular}{|l|r|}
\hline \multicolumn{2}{|c|}{ National indicators: household ownership of technology } \\
\hline Radio & $40.2 \%$ \\
\hline Television & $35.7 \%$ \\
\hline Telephone - fixed line & $2.2 \%$ \\
\hline Telephone - mobile & $89.4 \%$ \\
\hline Computer & $15.2 \%$ \\
\hline Access to the internet at home & $30.3 \%$ \\
\hline
\end{tabular}

At the school level, 55\% of primary schools have access to electricity compared to $71.5 \%$ of secondary schools (Table 4). Internet connectivity is low across both primary and secondary schools, at $26.25 \%$ and $42.76 \%$ respectively. Primary and secondary school institutions cite the high cost of equipment and internet service as the primary 
reasons for not having access to the internet. There is a shortage of computers across all levels, particularly at the primary-school level where there are on average, 126 learners per computer.

Table 4. School and learner information (Ministry of Primary and Secondary Education, 2019)

\begin{tabular}{|c|c|}
\hline \multicolumn{2}{|l|}{ School and learner Information } \\
\hline Number of primary schools & 6,288 \\
\hline Number of secondary schools & 2,871 \\
\hline Number of primary school students (aged 8-12) & $2,725,970$ \\
\hline Number of lower secondary school students (aged 13-16) & 996,790 \\
\hline Number of upper secondary school students (aged 17-18) & 96,760 \\
\hline Number of primary school teachers & 72,512 \\
\hline Number of secondary school teachers & 46,160 \\
\hline \multicolumn{2}{|l|}{ Indicators: school ICT infrastructure } \\
\hline Proportion of primary schools with access to electricity & $55.0 \%$ \\
\hline Proportion of secondary schools with access to electricity & $71.5 \%$ \\
\hline $\begin{array}{l}\text { Proportion of schools with access to alternative power sources } \\
\text { (solar, generators, etc.) }\end{array}$ & $\begin{array}{r}\text { at least } \\
5 \%\end{array}$ \\
\hline Proportion of primary schools with internet connectivity & $26.25 \%$ \\
\hline Proportion of secondary schools with internet connectivity & $42.76 \%$ \\
\hline Average number of computers per primary school & 6 \\
\hline Average number of computers per secondary school & 18 \\
\hline Average number of learners per computer in primary schools & 123 \\
\hline Average number of learners per computer in secondary schools & 36 \\
\hline
\end{tabular}

In 2017, Zimbabwe's National Statistical Agency (ZIMSTAT), conducted an ICT census to document access to and use of ICT in education institutions (Zimbabwe National Statistics Agency, 2017). It also aimed to identify geographical areas with limited use of ICTs and key barriers to ICT use in education. Table 5 indicates the numbers of computers used in primary and secondary schools and the location in which they are used. The census found that most computers were used for data storage followed by copying or moving a file or folder. 
Table 5. Number of computers used and their location (Zimbabwe National Statistics Agency, 2017)

\begin{tabular}{|l|r|r|r|r|}
\hline Type of School & Computer Labs & Classrooms & \multicolumn{1}{|l|}{ Libraries } & \multicolumn{1}{|l|}{ Portable } \\
\hline $\begin{array}{l}\text { Primary } \\
\text { schools }\end{array}$ & 18,886 & 4,318 & 686 & 8,609 \\
\hline $\begin{array}{l}\text { Secondary } \\
\text { schools }\end{array}$ & 22,280 & 4,741 & 1,726 & 6,609 \\
\hline
\end{tabular}

\section{Key partners and initiatives in EdTech}

This section looks at the work and roles and responsibilities of key partners with regard to EdTech in Zimbabwe, including government and non-governmental agencies, as well as EdTech initiatives.

\subsection{Government agencies}

The responsibility for designing and implementing EdTech initiatives is shared across different agencies in Zimbabwe. Table 6 describes the role that different agencies are currently playing in supporting EdTech.

Table 6. Agencies with EdTech roles

\begin{tabular}{|c|c|}
\hline Ministry / Agency & Roles and responsibilities in EdTech \\
\hline $\begin{array}{l}\text { Curriculum Development Unit in the } \\
\text { Education Ministry's Curriculum } \\
\text { Development and Technical Services } \\
\text { Department }{ }^{1}\end{array}$ & $\begin{array}{l}\text { - Designs new instructional system } \\
\text { and strategies for production of } \\
\text { multimedia learning materials } \\
\text { - Develops and disseminates } \\
\text { learning resources like video } \\
\text { programmes and computer-assisted } \\
\text { instructional multimedia packages to } \\
\text { schools }\end{array}$ \\
\hline $\begin{array}{l}\text { Centre for Educational Research, } \\
\text { Innovation and Development }{ }^{2}\end{array}$ & $\begin{array}{l}\text { - Guides research and innovation in } \\
\text { the deployment and use of ICTs } \\
\text { effectively and efficiently in education } \\
\text { - } \quad \text { Facilitates provision of up-to-date } \\
\text { research-based data, information and }\end{array}$ \\
\hline
\end{tabular}

\footnotetext{
${ }^{1}$ Ministry of Primary and Secondary Education (2020b), available at http://mopse.co.zw/department/curriculum-development-and-technical-services-department

${ }^{2}$ Ministry of Primary and Secondary Education (2020a), available at http://mopse.co.zw/department/centre-education-research-innovation-and-development
} 


\begin{tabular}{|c|c|}
\hline & $\begin{array}{l}\text { practical knowledge on the use of ICTs to } \\
\text { improve instruction }\end{array}$ \\
\hline $\begin{array}{l}\text { National Library and Documentation } \\
\text { Services }\end{array}$ & $\begin{array}{l}\text { - Facilitates sharing and supply of } \\
\text { resources through access to } \\
\text { international electronic bibliographic and } \\
\text { information networks, databases and } \\
\text { resources }\end{array}$ \\
\hline $\begin{array}{l}\text { Zimbabwe Schools Examinations } \\
\text { Council }^{3}\end{array}$ & $\begin{array}{l}\text { - Is an autonomous examinations } \\
\text { board; sets standards for levels of } \\
\text { academic expertise including ICT }\end{array}$ \\
\hline $\begin{array}{l}\text { Ministry of ICT, Postal and Courier } \\
\text { Services }^{4}\end{array}$ & $\begin{array}{l}\text { - } \quad \text { Develops, manages and maintains } \\
\text { central government ICT infrastructure } \\
\text { - } \quad \text { Facilitates the implementation of } \\
\text { the Presidential e-Learning programmes } \\
\text { in schools }\end{array}$ \\
\hline $\begin{array}{l}\text { Ministry of Information, Publicity and } \\
\text { Broadcasting Services }^{5}\end{array}$ & $\begin{array}{l}\text { - Promotes the use of ICTs; recently } \\
\text { the Zimbabwe Broadcasting } \\
\text { Corporation partnered with } \\
\text { MoPSE to launch radio lessons }\end{array}$ \\
\hline
\end{tabular}

\subsection{Non-governmental agencies}

UN agencies such as UNESCO have managed EdTech initiatives such as the ICT Transforming Education in Africa' project from 2016 to 2019 which had the aim of increasing access through innovative solutions (e-Schools Model), facilitating the development of national ICT in education policies and master plans, strengthening teacher training and higher education systems.

Additionally, organisations such as FBC Bank have partnered with MoPSE to provide EdTech equipment including tablets, laptops, projectors and interactive whiteboards to 20 primary and secondary schools. Established in 2000, e-learning solutions is a private for-profit corporation that provides instructional design and interactive digital multimedia tools to schools.

\subsection{EdTech initiatives}

The Government of Zimbabwe has introduced several initiatives aimed at promoting the use of technology in education over the last ten years. These activities include:

\footnotetext{
${ }^{3}$ Zimbabwe School Examinations Council (2020), available at https://www.zimsec.co.zw/

${ }^{4}$ Ministry of ICT, Postal and Courier Services (2020), available at http://www.ictministry.gov.zw/

${ }^{5}$ Ministry of Information, Publicity and Broadcasting Services (2020), available at http://www.zim.gov.zw/index.php/en/my-government/government-ministries/information,-publi city-and-broadcasting-services
} 
- The Presidential Schools Computerisation Programme launched in 2000 where more than $25 \%$ of schools received computers and printers

- The Presidential e-Learning Programme of 2011 which aimed to strengthen the use of ICTs for teaching and learning

- The Connect a School-Connect a Community Project of 2013 which provided disadvantaged schools with modern technology

- The Curriculum Framework (2015 - 2022) which prepares learners for a 21st-century environment dominated by ICTs

- E-learning content development in schools

- Teacher professional development activities carried out in partnership with various universities

- Implementation of e-registration and e-marking by the Schools Examinations Council (ZIMSEC)

- Introduction of an Electronic Ministry Application Platform (e-MAP) used for school applications

- Introduction of an electronic Institution Inspection Report which is used by schools to generate the school reports

- Introduction of an e-Recruitment platform which is used for teacher recruitment

Some of the main challenges that inhibit the effective use of EdTech in education include the limited power supply, low broadband coverage in rural and remote areas, a lack of equipment, limited financial resources for EdTech-related programmes, and a lack of awareness and skill in effectively integrating EdTech in teaching and learning content, to improve student learning outcomes.

Table 7 highlights recent and large-scale EdTech initiatives for which MoPSE has provided endorsement or has been an implementing partner. Several of the initiatives were launched to support continued teaching and learning during the Covid-19 pandemic.

Table 7. Recent EdTech initiatives in Zimbabwe

\begin{tabular}{|l|l|}
\hline Initiative & Details \\
\hline Ruzivo Digital Learning & \\
& $\begin{array}{l}\text { Overview: Ruzivo is an interactive digital learning } \\
\text { platform. } \\
\text { Target group Primary and high school learners; all } \\
\text { content is aligned to the national curriculum and has } \\
\text { been approved by the Ministry of Primary and } \\
\text { Secondary Education. } \\
\text { Technology: Basic mobile phones are used to deliver } \\
\text { supplementary learning and revision materials to } \\
\text { students. }\end{array}$ \\
\hline
\end{tabular}

${ }^{6}$ Ruzivo Digital Learning (2020), available at https://www.ruzivodigitallearning.co.zw/ 


\begin{tabular}{|c|c|}
\hline & $\begin{array}{l}\text { Reach / scale: As at } 2020 \text { it reported to have 1,6 } \\
\text { million students. } \\
\text { Implementing organisations: Higher Life Foundation } \\
\text { Government partners: MoPSE } \\
\text { Status of implementation: Ongoing }\end{array}$ \\
\hline Teaching by radio & $\begin{array}{l}\text { Overview: In response to Covid-19, the Ministry of } \\
\text { Primary and Secondary Education in conjunction with } \\
\text { the national broadcaster, Zimbabwe Broadcasting } \\
\text { Corporation, and with funding from UNICEF, launched } \\
\text { radio lessons. The content currently available is for } \\
\text { primary schools and was produced by volunteer } \\
\text { teachers during the country's lockdown. Content for } \\
\text { secondary school learners is currently being } \\
\text { produced. Plans are for the initiative to continue } \\
\text { beyond the pandemic. } \\
\text { Target group Primary and high school learners } \\
\text { Technology: Radio } \\
\text { Reach / scale: Country-wide } \\
\text { Implementing organisations: MoPSE and ZBC } \\
\text { Status of implementation: Launched on } 3 \text { June } 2020\end{array}$ \\
\hline $\begin{array}{l}\text { Akello Digital } \\
\text { Classroom }^{7}\end{array}$ & $\begin{array}{l}\text { Overview: Akello is an e-learning platform that also } \\
\text { allows students to access pre-recorded video lessons, } \\
\text { slides and exercises. It offers students access to online } \\
\text { Zimbabwe School Examinations Council curriculum } \\
\text { lessons for all subjects. The organisation has } \\
\text { partnered with several publishers to provide an online } \\
\text { library platform that offers access to a wide variety of } \\
\text { ZIMSEC prescribed textbooks. } \\
\text { Target group Primary and secondary school learners; } \\
\text { tertiary-level learners } \\
\text { Technology: Digital } \\
\text { Implementing organisations: Cassava Smartech (a } \\
\text { diversified digital services group) } \\
\text { Status of implementation: } 2020 \text { - present }\end{array}$ \\
\hline
\end{tabular}

${ }^{7}$ Akello Digital Classroom (2020), available at https://www.akellobooks.com/live-class.html 


\begin{tabular}{|c|c|}
\hline TelOne Learners Tab $^{8}$ & $\begin{array}{l}\text { Overview: interactive digital education platform which } \\
\text { can be accessed online or offline. It comprises video } \\
\text { tutorials and interactive tests in Mathematics, English, } \\
\text { Biology, Physics and Chemistry } \\
\text { Target group Secondary school learners ('O' Level) } \\
\text { Technology: It is available online through a website } \\
\text { streaming service; it is also available offline through a } \\
\text { micro SD card which works on mobile platforms. } \\
\text { Implementing organisations: TelOne (parastatal } \\
\text { telecommunications company) } \\
\text { Status of implementation: } 2020 \text { - present }\end{array}$ \\
\hline $\begin{array}{l}\text { ICT Transforming } \\
\text { Education in Africa } \\
\text { Project }^{9}\end{array}$ & $\begin{array}{l}\text { Overview: The 'ICT Transforming Education in Africa' } \\
\text { project prepared within the UNESCO-Korea Funds in } \\
\text { Trust cooperation was implemented between } 2016 \\
\text { and } 2019 \text { in Mozambique, Rwanda and Zimbabwe, } \\
\text { The overall project aimed to increase access and } \\
\text { quality of basic education through innovative ICT } \\
\text { solutions; strengthen higher education systems } \\
\text { through ODL; facilitate the development of national } \\
\text { ICT in education policies and master plans and } \\
\text { knowledge-sharing. } \\
\text { Target group: Policy-makers, educational } \\
\text { administrators, teacher educators, pre- and in-service } \\
\text { teachers, higher education institutions, primary and } \\
\text { secondary public schools. } \\
\text { Technology: Digital } \\
\text { Implementing organisations: UNESCO, Korea } \\
\text { Funds-in-Trust } \\
\text { Government partners: MoPSE, Ministry of Higher } \\
\text { and Tertiary Education, Science and Technology } \\
\text { Development } \\
\text { Status of implementation: } 2016-2019\end{array}$ \\
\hline
\end{tabular}

\section{Covid-19 education response}

Schools in Zimbabwe closed on 24 March 2020 due to the Covid-19 outbreak. The education-related Covid-19 preparedness and response activities are led by MoPSE with the support of Education Cluster partners. The partners include United Nations

\footnotetext{
${ }^{8}$ TelOne (2020), available at https://www.telone.co.zw/News/Details/telone-launches-digital-education-platform${ }^{9}$ UNESCO (2017), available at https://unesdoc.unesco.org/ark:/48223/pf0000260523
} 
agencies, international and local Non-Governmental Organisations (NGOs), donor agencies as well as Civil Society Organisations (CSOs).

The EdTech-related aspects of the response include implementing alternative learning interventions that include radio programming, digital and online learning and the provision of supplementary learning materials. Radio is the most prevalent mass communication medium capable of reaching the highest number of out-of-school children. For learners with access to the internet and computers, online learning platforms such as Ruzivo by Higher Life Foundation will be used to ensure continuous learning. The Ministry of Primary and Secondary Education and partners will support the development of a proprietary learning platform; UNESCO has been supporting the MoPSE to develop an online platform, which is being revamped for use. One of the strategic priorities articulated in the Education Sector Response Plan is to provide learners, teachers and parents who support children in learning, with materials such as storybooks or readers, workbooks and open and distance learning modules as well as additional textbooks.

Teacher Capacitation is one of the strategic priority areas of the Covid-19 Response Plan, that aims to equip teachers with both technical skills and adaptive capacities to enable them to respond effectively to the learning needs of children, especially those from vulnerable groups. The response strategy envisions strengthening the capacities of teachers to enable them to supplement teaching and learning through radio, digital and online programmes. This implies training teachers on open and distance learning modalities as well as helping them to support families and children from home.

\section{Looking ahead}

Zimbabwe recognises the importance of EdTech and the competitive advantage in working to become a knowledge-based society. The government's commitment to EdTech is apparent through the initiatives it has implemented over the years, and more recently through the development of the ICT Policy for Primary and Secondary Education. However, challenges related to a lack of basic school infrastructure, inadequate EdTech equipment, expensive connectivity, limited knowledge and capacity among administrative and teaching staff, and limited government funding for EdTech, collectively inhibit the extent and scale to which EdTech projects can be implemented and scaled.

To address these challenges, a strategy for addressing infrastructure constraints such as the lack of regular and readily available power and inadequate classroom furniture should be prioritised. Issues related to the availability and equitable distribution of EdTech equipment - using measures such as learner-to-equipment ratios — need to be addressed to ensure all learners have access to tools that can help them achieve the greatest gains in learning. To address the issue of limited internet connectivity in schools, public-private partnerships with mobile network operators and internet service providers could be explored. Finally, including EdTech in pre-service teacher curricula would help to increase the awareness and capacity of incoming teachers to effectively use technology to enhance teaching and learning. 


\section{Further reading}

Kaye, T., Groeneveld, C., Moss, C., \& Haßler, B. (2020). Nepal "Ask me anything" Session: Responses to audience questions (EdTech Hub Helpdesk Response No. 13). EdTech Hub.

Moss, C. (2020a, January 22). 18 large-scale EdTech initiatives on our radar in 2020. The EdTech Hub.

Moss, C. (2020b, January 24). 15 EdTech research papers that we share all the time. The EdTech Hub.

Trucano, M. (2013). 10 principles to consider when introducing ICTs into remote, low-income educational environments.

https://blogs.worldbank.org/edutech/10-principles-consider-when-introducing-icts -remote-low-income-educational-environments 


\section{References}

Akello Digital Classroom. (2020). Akello Digital Classroom | Home. https://www.akellobooks.com/live-class.html

Government of Zimbabwe. (1987). National Education Act. http://www.unesco.org/education/edurights/media/docs/d0945389cdf8992e8cb5f3 a4b05ef3b3aa0e6512.pdf

Government of Zimbabwe. (2019). Education Amendment Act. https://www.veritaszim.net/sites/veritas d/files/EDUCATION\%20AMENDMENT\%20A CT\%2C\%202019\%20\%5B\%20Act\%2015-2019\%5D 0.pdf

Kadirire, H. (2020). Zim tops Cambridge International exam entries. Daily News (Zimbabwe).

https://dailynews.co.zw/zim-tops-cambridge-international-exam-entries/

Kaye, T., Groeneveld, C., Moss, C., \& Haßler, B. (2020). Nepal "Ask me anything" Session: Responses to audience questions (EdTech Hub Helpdesk Response No. 13). EdTech Hub.

Ministry of ICT, Postal and Courier Services (Zimbabwe). (2016). National Policy for Information and Communications Technology.

http://www.veritaszim.net/sites/veritas d/files/Zimbabwe\%20National\%20Policy\%20 for\%20ICT\%202016.pdf

Ministry of ICT, Postal and Courier Services (Zimbabwe). (2020). Ministry of ICT Postal \& Courier Services | Home. http://www.ictministry.gov.zw/

Ministry of Information, Publicity and Broadcasting Services (Zimbabwe). (2020). Ministry of Information, Publicity and Broadcasting Services | Home.

http://www.zim.gov.zw/index.php/en/my-government/government-ministries/infor mation,-publicity-and-broadcasting-services

Ministry of Primary and Secondary Education (Zimbabwe). (2016). Education Sector Strategic Plan (2016-2020).

https://www.globalpartnership.org/sites/default/files/2016-07-education-sector-stra tegic-plan.pdf

Ministry of Primary and Secondary Education (Zimbabwe). (2018). Primary and Secondary Education Statistics Report.

https://www.globalpartnership.org/sites/default/files/2016-07-education-sector-stra tegic-plan.pdf

Ministry of Primary and Secondary Education (Zimbabwe). (2019a). ICT Policy for Primary and Secondary Education (2019-2023).

Ministry of Primary and Secondary Education (Zimbabwe). (2019b). Primary and Secondary Education Statistics Report. https://www.globalpartnership.org/sites/default/files/2016-07-education-sector-stra tegic-plan.pdf 
Ministry of Primary and Secondary Education (Zimbabwe). (2020a). Centre of Education, Research, Innovation and Development.

http://mopse.co.zw/department/centre-education-research-innovation-and-develop ment

Ministry of Primary and Secondary Education (Zimbabwe). (2020b). Curriculum Development and Technical Services Department.

http://mopse.co.zw/department/curriculum-development-and-technical-services-de partment

Moss, C. (2020a, January 22). 18 large-scale EdTech initiatives on our radar in 2020. The EdTech Hub.

https://edtechhub.org/2020/01/22/18-large-scale-edtech-initiatives-on-our-radar-in$\underline{2020 /}$

Moss, C. (2020b, January 24). 15 EdTech research papers that we share all the time. The EdTech Hub. https://doi.org/10.5281/zenodo.3690149

Musarurwa, T. (2018). Constant review vital for National ICT Policy. The Sunday Mail (Zimbabwe).

https://www.sundaymail.co.zw/constant-review-vital-for-national-ict-policy

Ngwenya, R. (2018). Financing key to accessing quality education for all. Zimbabwe Situation.

https://www.zimbabwesituation.com/news/financing-key-to-accessing-quality-educa tion-for-all/

Ruzivo Digital Learning. (2020). Ruzivo Digital Learning | Home.

https://www.ruzivodigitallearning.co.zw/

TelOne. (2020). TelOne | Home.

https://www.telone.co.zw/News/Details/telone-launches-digital-education-platform-

Trucano, M. (2013). 10 principles to consider when introducing ICTs into remote, low-income educational environments.

https://blogs.worldbank.org/edutech/10-principles-consider-when-introducing-icts-r emote-low-income-educational-environments

UNESCO. (2017). ICT Transforming Education in Africa.

UNICEF. (2019). Multiple Indicator Cluster Survey Findings Report: Zimbabwe. https://www.unicef.org/zimbabwe/media/2536/file/Zimbabwe\%202019\%20MICS\%2 0Survey\%20Findings\%20Report-31012020 English.pdf

World Bank. (2019). The World Bank In Zimbabwe.

https://www.worldbank.org/en/country/zimbabwe/overview

ZBC News. (2020). Government launches school radio lessons programme. https://www.zbcnews.co.zw/min-primary-secondary-education-launches-school-radi o-programme/

Zimbabwe Education Cluster. (2020). Zimbabwe COVID-19 preparedness and response strategy. 
https://resourcecentre.savethechildren.net/node/17564/pdf/zimbabwe education c luster covid strategy 12.05.2020 final.pdf

Zimbabwe National Statistics Agency. (2017). Information and Communications Technology (ICT) Census.

Zimbabwe School Examinations Council. (2020). ZIMSEC | Home.

https://www.zimsec.co.zw/ 